\title{
MANAJEMEN PEMBAHARUAN PESANTREN DI TENGAH TANTANGAN KEHIDUPAN MASARAKAT GLOBAL
}

\author{
MOH. AFIFUL HAIR \\ Universitas Islam Madura (UIM) Pamekasan \\ affkhir@gmail.com
}

\begin{abstract}
Pesantren as education institute obliged to perform a renewal refitalisation and utilize to yield taft generations, well informed generation with strength soul of pesantren firmness and develop knowledge which remain to coming from alqur'an and hadis. In growth of era, pesantren in this time deal with globalization current and modernization marked swiftly fast of technology and information. In consequence, pesantren have to make a change format, form, education method and orientation with note do not change vision, orientation and mission of pesantren.
\end{abstract}

\begin{abstract}
Abstrak
Pesantren sebagai lembaga pendidikan diharuskan mengadakan refitalisasi dan pembaharuan guna menghasilkan generasi-generasi yang tangguh, generasi yang berpengetahuan luas dengan kekuatan jiwa pesantren dan keteguhan mengembangkan pengetahuan yang tetap bersumber pada al-qur'an dan hadis. Dalam perkembangan zaman, pesantren saat ini berhadapan dengan arus globalisasi dan modernisasi yang ditandai dengan cepatnya laju informasi dan teknologi. Karena itu, pesantren harus melakukan perubahan format, bentuk, orientasi dan metode pendidikan dengan catatan tidak sampai merubah visi, misi dan orientasi pesantren.
\end{abstract}

\section{Kata Kunci: Revitalisasi, Manajemen, Pesantren, globalisasi}

\section{Pendahuluan}

Setiap kali kita berbicara tentang pendidikan, tentu masih banyak masalah yang harus segera diselesaikan. Baik itu dari sisi pemerintah, masyarakat, dan pendidik, semua berhak punya kesempatan dalam memperbaiki dunia pendidikan. Jika dilihat dari sisi pendidikan Islam itu sendiri, masih banyak sekali permasalahan yang patut dibahas dan dicarikan solusi kedepannya. Salah satunya yaitu masalah pesantren.

Perkembangan dari masa ke masa pesantren di Indonesia sudah banyak dilakukan para kyai yang ingin merespon ketertinggalan pendidikan yang berjalan di pesantren. Pemerintah juga sudah mendorong dengan berbagai kebijakan untuk memajukan pesantren. Sudah banyak pesantren yang mengembangkan pendidikannya dengan mendirikan madrasah dan sekolah, namun masih ada juga pesantren yang anti dengan dunia modern yang berkembang sekarang dan masih bertahan dengan ketradisionalannya. Masih ada 
pesantren yang melarang santrinya untuk bersekolah disekolah formal, dan masih ada pula pesantren yang membatasi santrinya dengan dunia luar termasuk teknologi. Sehingga masih banyak output pesantren yang begitu keluar dari pesantren gagap dengan dunia yang dihadapinya.

Pengembangan manajemen pesantren merupakan salah satu solusi yang dapat digunakan untuk meningkatkan kualitas atau mutu pesantren. Manajemen mengawal dan memberikan arahan pada proses berjalannya sebuah lembaga pesantren dapat terpantau. Tak berbeda dengan lembaga pedidikan lain seperti sekolah formal, pendidikan pesantren juga membutuhkan manajemen untuk mengembangkan atau memajukan sebuah pesantren terlebih ketika pesantren berada dalam konteks pusaran global termasuk didalamnya adalah masyarakat ekonomi asia (MEA). Pesantern sebagai pendidikan nonformal adalah sebuah lembaga pendidikan dan penyiaran agama Islam.1 Dengan demikian pesantren sebagai lembaga pendidikan yang bersifat nonformal harus mengadakan perubahan dan pembaharuan guna menghasilkan generasi-generasi yang tangguh, generasi yang berpengetahuan luas dengan kekuatan jiwa pesantren dan keteguhan mengembangkan pengetahuan yang tetap bersumber pada al-qur'an dan hadis.

Pada perkembangan zaman,pesantren saat ini berhadapan dengan arus globalisasi dan modernisasi yang ditandai dengan cepatnya laju informasi dan teknologi. "Karena itu, pesantren harus melakukan perubahan format, bentuk, orientasi dan metode pendidikan dengan catatan tidak sampai merubah visi, misi dan orientasi pesantren itu, akan tetapi perubahan tersebut hanya pada sisi luarnya saja, sementara pada sisi dalam masih tetap dipertahankan.

Pesantren sebagai lembaga pendidikan yang bersifat nonformal harus mengadakan perubahan dan pembaharuan guna menghasilkan generasi-generasi yang tangguh, generasi yang berpengetahuan luas dengan kekuatan jiwa pesantren dan keteguhan mengembangkan pengetahuan yang tetap bersumber pada al-qur'an dan hadis. Dalam perkembangan zaman,pesantren saat ini berhadapan dengan arus globalisasi dan modernisasi yang ditandai dengan cepatnya laju informasi dan teknologi. "Karena itu, pesantren harus melakukan perubahan format, bentuk, orientasi dan metode pendidikan dengan catatan tidak sampai merubah visi, misi dan orientasi pesantren itu, akan tetapi perubahan tersebut hanya pada sisi luarnya saja, sementara pada sisi dalam masih tetap dipertahankan.

Eksistensi pondok pesantren dalam menyikapi perkembangan zaman, tentunya memiliki komitmen untuk tetap menyuguhkan pola pendidikan yang mampu melahirkan SDM yang handal.

\section{Sejarah Pesantren di Indonesia.}


Kata pesantren berasal dari kata santri yang diberi awalan pe- dan akhiran -an yang menunjuk arti kata tempat. Kata santri itu sendiri merupakan gabungan dari dua suku kata yaitu sant (manusia baik) dan tra (suka menolong), sehingga kata pesantren dapat berarti tempat pendidikan untuk membina manusia menjadi orang yang baik. Pondok pesantren adalah lembaga keagamaan, yang memberikan pendidikan dan pengajaran serta mengembangkan dan menyebarkan ilmu agama dan Islam.2 Selanjutnya KH. Muchtar Rasidi berpendapat pondok pesantren adalah ; pertama, lembaga Pembina karakter buildingbangsa. Kedua, panti pendidikan kepribadian bangsa. Ketiga, tempat pemupukan jiwa gotong-royong. Keempat, arena pendidikan self help. Kelima, kancah penggemblengan jiwa patriotism dengan doktrin.3

Pada sejarah awal berdirinya, pesantren mengkonsentrasikan diri pada tiga fungsi utamanya yaitu : mengajarkan atau menyebar luaskan ajaran Islam, mencetak para ulama, menanamkan tadisi Islam dalam masyarakat.4 Kurikulum dalam pesantren sampai awal abad ke 20 belum digunakan. Dengan kata lain, sistem pembelajaran lebih ditekankan pada pemahaman kitab secara apa adanya, dan memberikan pembedaan arahan pembelajaran dan pendidikan hanya didasarkan pada kategorisasi perbedaan kitab semata.5 Sebelum masuknya sistem madrasah bakat dan kemampuan santri di pesantren tidak mendapatkan perhatian dari kyai dan pembantunya.6 Selanjutnya sebagaimana kita ketahui bahwa akhir-akhir ini hampir semua pesantren telah mengubah dan mengembangkan dirinya memiliki madrasah.

Era 1970-an perubahan dan perkembangan pesatren dapat dilihat dari dua sudut pandang. Pertama, pesantren mengalami perkembangan jumlah yang luar biasa. Kedua, menyangkut penyelenggaraan pendidikan dapat diklasifikasikan menjadi empat tipe yakni :pertma, Pesantren yang mendirikan pendidikan formal dan menerapkan kurikulum nasional.Kedua, Pesantren yang menyelenggarakan pendidikan keagamaan dalam bentuk madrasah dan mengajarkan ilmu-ilmu umum meski tidak menerapkan kurikulum nasional. Ketiga, Pesantren yang hanya mengajarkan ilmu-ilmu agama dalam bentuk Madrasah Diniyah.Keempat, Pesantren yang hanya sekedar menjadi tempat pengajian.7

Pondok pesantren secara garis besar dapat dikelompokkan, sebagaimana dituangkan dalam PMA No.3 Tahun 1979 yang mengkategorikan pondok pesantren menjadi :

a. Pondok pesatren tipe A yaitu pondok pesantren yang seluruhnya dilaksanakan secara tradisional.

2 Ridlwan Nasir, Mencari Tipologi Format Pendidikan Ideal (Yogyakarta: Pustaka Pelajar, 2005), 80.

3. Suismanto, Menelusuri Jejak Pesantren, (Yogyakarta: Alif press, 2004), 49.

4. Abudin Nata, Sejarah Sosial Intelektual Islam dan Institusi Pendidikannya, (Jakarta: PT Raja Grafindo Persada, 2012), 321.

5. Abdur Rahman Asegaf, Pendidikan Islam di Indoonesia, (Yogyakarta : Suka Press, 2007), 91.

6. Suismanto, Menelusuri Jejak Pesantren, (Yogyakarta: Alif press, 2004), 66.

7. Sulthon Masyhud, Manajemen Pondok Pesantren, (Jakarta: Diva Pustaka, 2005), 5. 
b. Pondok pesantren tipe B yaitu pondok yang menyelenggarakan pengajaran secara klasikal.

c. Pondok pesantren tipe $\mathrm{C}$ yaitu pondok pesantren yang hanya merupakan asrama sedangkan santrinya belajar diluar.

d. Pondok pesantren tipe D yaitu pondok pesantren yang menyelenggarakan sistem pondok pesantren dan sekaligus sistem sekolah atau madrasah. 8

Secara faktual ada beberapa tipe pondok pesantren yang berkembang dalam masyarakat, yang meliputi: (1) Pondok pesantren tradisional, (2) Pondok pesantren modern (khalafiyah/'Ashriyah), dan (3) Pondok pesantren komprehensif/campuran.

Pondok pesantren ini disebut komprehensif karena merupakan sistem pendidikan dan pengajaran gabungan antara tradisional dan yang modern. Artinya didalamnya diterapkan pendidikan dan pengajaran kitab kuning dengan metode sorogan, bandongan dan wetonan, namun secara regular sistem persekolahan terus dikembangkan.9 Perkembangan pesantren saat ini diharapkan dapat menumbuhkan atau bertambahnya pesantren yang berwawasan global, sehingga pesantren menjadi sebuah lembaga pendidikan Islam yang mampu beradaptasi dalam menhadapi arus globalisasi tanpa kehilangan jati diri, tetap memproduksi santri yang berakhlak baik dan mampu berkiprah di dunia global. .

\section{Potret Pendidikan Pesantren}

Pesantren yang diakui sebagai model pendidikan awal (Islam) di Indonesia sampai saat ini masih eksis dan diakui keberadaannya di masayarakat, meskipun tidak jarang di antara masyarakat membcarakan pengelolaan pendidikan pesantren yang masih kurang.

Pengelolaan pesantren yang apa adanya tersebut mudah dilihat dari kurikulum sebagai pesantren yang belum dikembangkan dan disesuaikan dengan perkembangan ilmu dan teknologi. Sebagai akibatnya, para alumni pesantren juga sering kali gagap dalam menghadapi tantangan zaman. Sebagai contoh, tatkala ada sebagian alumni pesantren yang menjadi tokoh masyarakat sebaga politisi, mereka seakan gagap menghadapi perannya yang baru karena mereka memang belum atau bahkan tidak mengetahui betul bagaimana "konstruksi polotik Islam" dan strategi berpolitik yang disebut-sebut sebagai high politic. Hal tersebut terjadi karena materi kajian yang diberikan di pesantren kurang dikontekstualkan dengan perkembangan zaman seperti fih politik/figh as-siyasah belum diberikan secara baik dan terstrukturkan dalam bangunan kurikulum pesantren.10

Bukti pengelolaan pesantren yang apa adanya adalah tenaga pengajar pesantren yang belum dipersiapkan secra sistematis sebgai ustadz profesional

8. DEPAG RI DIRJEN Kelembagaan Agama Islam, Pondok Pesantren dan Madrasah Diniyah Pertumbuhan dan Perkembangannya (Jakarta: DEPAG RI, 2003), 15.

9. Muwahid Shulhan, Manajemen Pendidikan Islam, (Yogyakarta: Teras, 2013), 155-157

10. Imam Machali, Pendidikan Islam dan Tantangan Globalisasi, (Yogyakarta: Presma dan Ar-Ruzz Media, 2004), 8-9. 
yang menguasaimaddah dan sekaligus mampu mempraktikan metode (thariqah) pembelajaran yang baik. Hal lain yang membuktikan lemahnya pengelolaan pesantren adalah jaringan sebagian pesantren juga diakui lemah, baik jaringan dengan sesama pesantren, masyarakat, pengusaha, maupun pemerintah. komunikasi yang dilakukan pesantren kurang intensif dan efektif. Hal lain yang bisa dijadikan bukti adalah rendahnya pengelolaan pembelajaran di pesantren bisa dilihat dari terbatasnya sarana dan prasarana yang dimilikinya. Padahal jika pesantren mampu meyakinkan stake holder bahwa ia mampu menyiapkan santri yang berkualitas maka pesantren tersebut akan mudah membangun jaringan yang kuat, yang memungkinkan kebutuhannya akan sarana dan prasarana terpenuhi dengan baik. Hal ini sudah terbukti di beberapa pesantren yang telah maju dan besar sehingga mereka mampu menggalang dukungan dana dari masyarakat melalui waqaf dan lainnya.11

Meski banyak kelemahan yang dimiliki oleh pesantren, sebagian besar di antaranya masih tetap mendapatkan tempat di hati masyarakat muslim Indonesia, Terlebih lagi pesantren yang memiliki figur kharismatik, mampu menjaga kualitas keilmuannya, berkonsentrasi penuh terhadap perkembangan keilmuannya para santri, dan mampu membangun komunikasi yang baik dengan komunitas sosial dan pemerintah. 12

\section{Pembaharuan Pendidikan Islam}

Pembaharuan Islam bukanlah sesuatu yang evolusioner, melainkan lebih cenderung devolusioner, dengan artian bahwa pembaharuan bukan merupakan proses perkembangan bertahap di mana yang datang kemudian lebih baik dari sebelumnya.13

Harun Nasution menyebut gerakan pembaharuan pemikiran Islam dengan istilah modernisasi pemikiran Islam yang mempunyai arti, seperti dikutip Azyumardi Azra sebagai suatu aliran, gerakan, pemikiran, dan usaha untuk mengubah paham, adat istiadat agar semuanya disesuiakan dengan pendapat dan keadaan baru yang timbul oleh kemajuan ilmu pengetahuan serta teknologi modern. Adapun modernisasi menurut KBBI, adalah suatu proses pergeseran sikap dan mentalitas sebagai warga masyarakat untuk bisa hidup sesuai dengan tuntutan hidup

masa

\section{kinihttp://www.blogger.com/blogger.g?blog|D=2958616030265940971 - ftn10.14}

Berbeda dengan Harun Nasution, Maulana Maududi menyebut pembaruan pemikiran Islam dengan istilah tajaddud-tajdid, istilah tersebut diartikan sebagai suatu gerakan pemurnian yang merupakan reaksi atas melemah

11. Umar Tirtarahardja, Pengantar Pendidikan, (Jakarta: DIKTI DEPDIKBUD, 1994), 157.

12. Hasbi Indra, Pendidikan Islam Melawan Globalisasi (Jakarta: Rida Mulia, 2005. Jakarta: PT Raja Grafindo Persada, 2012), 200.

13. Hasbi Indra, Pendidikan Islam Melawan Globalisasi (Jakarta: Rida Mulia, 2005. Jakarta: PT Raja Grafindo Persada, 2012), 200-201.

14. Pusat Bahasa Departemen Pendidikan Nasional, Kamus Bahasa Indonesia, (Jakarta: Pusat Bahasa, 2008), 919. 
dan membekunya karena ancaman dari luar, menurut Maulana Maududi, suatu gerakan bisa disebut sebagai pembaruan jika: (1) Merupakan usaha perbaikan kondisi masyarakat dengan membersihkan penyakit yang meracuninya; (2) Mencari letak permasalahan untuk menyelesaikannya; (3) Identifikasi kemampuan dirinya untuk melakukan pembaruan; (4) Upaya menciptakan perombakan pandangan dan pola berpikir masyarakat ke arah yang lebih baik; (5) Upaya perbaikan secara praksis; (6) Active dan responsive mengembangkan aplikasi Islam; dan (7) Merombak secara Internasional.15

Berdasarkan asumsi bahwa pembaruan pendidikan Islam bersumber dari upaya pembaruan pemikiran Islam, maka pembaruan pendidikan Islam diartikan sebagai pembaruan pemikiran yang dilakukan dalam bidang pemikiran maupun praktek pendidikan Islam. Dengan makna ini, pendapat manapun mengenai pembaruan pemikiran dapat disubtitutikan. Gerakan pembaruan pada dasarnya mengusung nilai-nilai seperti: nilai pembaruan, nilai perjuangan, nilai kemerdekaan pikiran agama dan pikiran, nilai persatuan dan solidaritas.

\section{Beberapa Pembaharuan Pesantren}

Pesantren merupakan lembaga pendidikan Islam yang tertua di Indonesia, disinyalir sebagai sistem pendidikan yang lahir dan tumbuh melalui kultur Indonesia yang bersifat "indogenous", yang mana telah mengadopsi model pendidikan sebelumnya yaitu dari pendidikan Hindu dan Budha sebelum kedatangan Islam.16 Pondok pesantren sebagai lembaga pendidikan Islam memiliki kekhasan, baik dari segi sistem maupun unsur pendidikan yang dimilikinya. perbedaan dari segi sistem, terlihar dari proses belajar mengajar yang cenderung sederhana, meskipun harus diakui ada juga pesantren yang memadukan sistem modern dalam pembelajarannya.17

Berdasarkan tujuan pendiriannya, pesantren hadir dilandasi sekurangkurangnya oleh dua alasan: pertama, pesantren dilahirkan untuk memberikan respon terhadap situasi dan kondisi sosial suatu masyarakat yang tengah pada runtuhnya sendi-sendi moral, melalui transformasi nilai yang ditawarkan (amar ma;ruf, nahyi munkar). Kedua, salah satu tujuan pesantren adalah menyebarluaskan informasi ajaran tentang universalitas Islam ke seluruh plosok nusantara yang berwatak pluralis, baik dalam dimensi kepercayaan, budaya maupun kondisi sosial masyarakat.18

Di tengah kompetisi sistem pendidikan yang ada, pesantren sebagai lembaga pendidikan tertua yang masih bertahan hingga kini tentua saja harus sadar bahwa penggiatan diri yang hanya pada wilayah keagamaan tidak lagi

15. Umar Tirtarahardja, Pengantar Pendidikan, (Jakarta: DIKTI DEPDIKBUD, 1994), 157.

16. DEPAG RI DIRJEN Kelembagaan Agama Islam, Pondok Pesantren dan Madrasah Diniyah Pertumbuhan dan Perkembangannya (Jakarta: DEPAG RI, 2003), 17.

17. DEPAG RI DIRJEN Kelembagaan Agama Islam, Pondok Pesantren dan Madrasah Diniyah Pertumbuhan dan Perkembangannya (Jakarta: DEPAG RI, 2003), 18-19.

18. Abudin Nata, Sejarah Sosial Intelektual Islam dan Institusi Pendidikannya, (Jakarta: PT Raja Grafindo

Persada, 2012), 308. 
memadai, maka dari itu pesantren harus proaktif dalam memberikan ruang bagi pembenahan dan pembaharuan sistem pendidikan pesantren dengan senantiasa harus selalu apresiatif sekaligus selektif dalam menyikapi dan merespon perkembangan dan pragmatisme budaya yang kian menggejala. Hal tersebut dapat dijadikan pertimbangan lain bagaimana seharusnya pesantren mensiasati fenomena tersebut dengan beberapa perubahan pesantren di bawah ini

\section{Pembaharuan Metode pembelajaran}

Model Pembelajaran pesantren pada mulanya populer menggunakan metodik-didaktif dalam bentuk sorogan, bandongan, halaqah dah hafalan. Menurut Mastuhu (1989: 131), pembaharuan metode pembelajaran mulai terjadi sekitar awal abad ke-20 atau tepatnya sekitar tahun 1970-an, dari polasorogan berubah menjadi sistem klasikal, tidak hanya itu, beberapa pendidikan keterampilan juga mulai masuk ke dunia pesantren, seperti bertani, berternak, kerajinan tangan mulai akrab dikehidupan santri sehari-hari. ini dimaksudkan untuk mengembangkan wawasan atau orientasi santri dari pandangan hidup yang selalu berpandangan ukhrowi, supaya seimbang dengan kehidupan duniawi.19

\section{Pembaharuan Kurikulum}

Pada umunya pesantren sebagai lembaga pendidikan Islam, materi pembelajarannya lebih mengutamakan pelajaran agama Islam yang bersumber dari kitab-kitab klasik, seperti tauhid, hadis, tafsir, fiqih dan sejenisnya. Kurikulum didasarkan pada tingkat kemudahan dan kompleksitas kitab-kitab yang dipelajari, mulai dari tingkat awal, menengah dan lanjut.20

Dalam perkembangannya, hampir setiap pesantren telah melakukan pembaharuan kurikulum dengan memasukkan pendidikan umum dalam kurikulum pesantren. Sifatnya bervariasi, ada pesantren yang memasukan pendidikan $30 \%$ agama dan $70 \%$ umum, adapula yang sebaliknya, yakni $80 \%$ agama dan sisanya pelajaran umum.

\section{Pembaharuan Evaluasi}

Kemampuan santri biasanya dievaluasi dengan keberhasilannya mengajarkan kitab kepada orang lain. Apabila audiensi merasa puas, maka santri yang bersangkutan dinilai telah lulus. Legalisasi kelulusannya adalah restu kiai bahwa santri tersebut diizinkan pindah untuk mempelajari kitab lain yang lebih tinggi tingkatannya dan boleh mengajarkan kitab yang dikuasainya kepada yang lain.

Pesantren yang telah mengadopsi pembaruan kurikulum, baik yang mengacu pada Departemen Agama maupun Departemen Pendidikan Nasional jelas telah meninggalkan model evaluasi tersebut. Model madrasi/klasikal evaluasinya sebagaimana madrasah pada umunya, yaitu menggunakan ujian

19. Muwahid Shulhan, Manajemen Pendidikan Islam, (Yogyakarta: Teras, 2013), 6.

20. Jamal Makmur Asmani, Manajemen Pengelolaan dan Kepemimpinan Pendidikan Profesional, (Yogyakarta: Diva Press, 2009), 78. 
resmi dengan memberikan angka-angka kelulusan serta tanda kelulusan seperti ijazah.21

\section{Pembaharuan Organisasi/ Manajemen}

Dalam konteks pembaharuan manajemen, meskipun peran kiai tetap dipandang penting, tetapi kiai tidak ditempatkan pada posisi penentu kebijakan secara tunggal. Dari sini kerja dimulai dengan pembagian unit-unit kerja sesuai urutan yang ditetapkan pimpinan pesantren. Ini berarti kekuasan kiai telah terdistrubusi kepada yang lain yang dipercaya untuk mengemban tugas, mekanisme kerja juga mulai diarahkan sesuai dengan visi dan misi pesantren. Berangkat dari hal tersebut, terkadang tetap diakui bahwa pola perencanaan pesantren umunya masih tergolong sederhana, seringkali program jangka pendek, menengah, dan jangka penjang tampak tumpang tindih. Akibatnya, programprogramn demikian sulit diukur tingkat pencapainnaya.22

\section{Prinsip-Prinsip Pembaharuan Yang Harus Ditegakkan Pesantren}

Proses globalisasi adalah suatu proses menuju keadaan budaya global yang pasti setuju atau tidak setuju memasuki budaya Indonesia yang pada akhirnya akan mengubah hal-hal yang mendasar dalam pandangan hidup dan mencukupi seluruh aspek kehidupan. Berangkat dari hal tersebut, KH. Ali Maksum menyatakan delapan prinsip-prinsip yang terlihat dan harus diterapkan dalam pemharuan pendidikan pesantren, yaitu:

a. Memiliki kebijaksanaan menurut ajaran Islam. Para santri dibantu agar mampu memahami makna hidup, keberadaan, peranana, serta tanggung jawabnya dalam kehidupan di masyarakat.

b. Memiliki kebebasan yang terpimpin. Setiap manusia memiliki kebebasan, tetapi kebebasan itu harus dibatasi karena kebebasan memiliki potensi anarkisme. Keterbatasan (ketidak bebasan) mengandung kecenderungan mematikan kreativitas, berangkat dari hak tersebut, maka pembatasan harus dibatasi. Inilah yang dimaksud kebebasan yang terpimpin, dan kebebasan inilah yang dibentuk oleh K.H. Ali Maksum dalam mengasuh santrinya

c. Berkemampuan mengatur diri sendiri. Pada umumnya santri harus dapat mengatur diri sendiri dan kehidupannya menuruti batasan yang telah diajarkan agama.

d. Memiliki rasa kebersamaan yang tinggi. Dalam hal kewajiban santri harus menunaikan kewajiban terlebih dahulu, sedangkan dalam hak-hak, para santri harus mendahulukan kepentingan orang lain sebelum kepentingan sendiri

e. Menghormati orang tua dan guru. Ini memang ajaran Islam, tujuan ini dicapai antara lain melalui penegakan berbagai pranata di pesantren

21. Muwahid Shulhan, Manajemen Pendidikan Islam, (Yogyakarta: Teras, 2013), 10.

22. Imam Machali, Pendidikan Islam dan Tantangan Globalisasi, (Yogyakarta: Presma dan Ar-Ruzz Media, 2004), 109-110. 
seperti mencium tangan guru, tidak membantah guru. Demiian juga terhadap orang tua, karena nilai-nilai ini sudah banyak terkikis di sekolahsekolah.

f. Cinta kepada ilmu. Menurut al-quran ilmu (pengetahuan) datang dari Allah, banyak hadis yang yang mengajarkan pentingnya menuntut ilmu dan menjaganya, maka dari itu para santri harus memandang ilmu sebagai sesuatu yang suci dan tinggi.

g. Mandiri. Apabila mengatur diri sendiri kita sebut otonomi, maka mandiri yang dimaksud adalah berdiri atas kekuasaan sendiri, sejak awal santri telah dilatih untuk mandiri, sperti kebanyakan masak sendiri, mengatur uang belanja sendiri, mencuci pakaian sendiri dan sebagainya.

h. Kesederhanaan. Dilihat secara lahiriah sederhana memang mirip dengan kemiskinan, padahal yang dimaksud sederhana contohnya di Pesantrern Krapyak adalah sikap hidup, yaitu sikap memandang sesuatu, terutama materi secara wajar, proporsional dan fungsional.

Sebenarnya banyak para santri yang berlatar belakang orang kaya, mereka dilatih hidup sederhana. Ternyata orang kaya tidak sulit menjalani kehidupan sederhana bila dilatih seperti di kehidupan pesantren, apa yang melatih mereka? kondisi pesantren itulah yang melatih mereka. Di sini kita melihat bahwa pesantren adalah suatu sistem; yang kondisi itu merupakan salah satu elemennya. kesederhanaan itu sesungguhnya realisasi keimanan dari ajaran Islam yang pada umunya telah diajarkan para sufi. Hidup secara sufi memang merupakan suatu yang khas pada umumnya.23

\section{Tantangan Dan Hambatan Pendidikan Pesantren Di Era Modernitas}

Pondok pesantren Islam sebetulnya banyak berperan mendidik sebagian bangsa Indonesia sebelum lahirnya lembaga-lembaga pendidikan lain yang cenderung mengikuti pola 'Barat' yang modern, maka dari itu, lembaga pendidikan pesantren sering dijuluki sebagai basis pendidikan tradisional yang khas Indonesia.

Tantangan dan harapan masyarakat akan adanya suatu pesantren yang berkualitas semakin marak. Pesantren diharapkan memberi sesuatu dan mereflesikan kebutuhan konsumen, namun harapan ini tidak mudah direalisasikan dengan cepat karena peningkatan mutu pesantren lebih merupakan proses daripada hanya kejadian seketika. Sebagai pendidikan alternatif, tantangan yang dihadapi pesantren semakin hari semakin besar, kompleks dan mendesak, sebagai akibat meningkatnya kebutuhan pembangunan dan kemajuan ilmu pengetahuan dan teknologi. Sementara itu, perkembangan fisik bangunan pesantren juga mengalami kemajuan-kemajuan yang sangat observable, banyak pesantren di berbagai tempat, apakah wilayah urban, maupun pedesaan mempunyai gedung atau bangunan yang megah dan dan lebih penting lagi, sehat

23. Hasbi Indra, Pendidikan Islam Melawan Globalisasi (Jakarta: Rida Mulia, 2005. Jakarta: PT Raja Grafindo Persada, 2012), 59 
dan kondusif sebagai tempat berlangsungnya proses pendidikan yang baik. dengan demikian, citra yang pernah disandang pesantren sebagai kompleks bangunan yeng reot dan tidak higienis semakin memudar.24

Tantangan di atas menyebabkan terjadinya pergeseran nilai-nilai di pesantren baik nilai yang menyangkut pengelolaan pendidikan, di samping itu pula pesantren masih mempunyai beberapa kelemahan yang menjadi penghambat, adapun kelemahan-kelemahan tersebut adalah Manajemen pengelolaan pondok pesantren, Kaderisasi pondok pesantren, Belum kuatnya budaya demokrasi dan disiplin, hal ini memang berkaitan erat dengan pondok pesantren yang independen, dan Kebersihan di lingkungan pesantren.25

Selain kelemahan-kelemahan di atas, yang menjadi penghambat yaitu: Sebagian masyarakat memandang pesantren sebagai lembaga pendidikan kelas dua dan hanya belajar agama saja, Terbatasnya tenaga yang berkualitaas, khususnya mata pelajaran umum, Terbatasnya sarana yang memadai, baik sarana maupun ruang belajar, Masih dominannya sikap-sikap menerima apa adanya dikalangan sebagian pesantren, dan Sebagian pesantren masih bersifat ekslusif .

Apabila mencari pendidikan yang asli Indonesia dan berakar dalam masyarakat, tentu akan menempatkan pesantren di tangga teratas, namun ironisnya lembaga yang dianggap merakyat ini ternyata masih menyisihkan berbagai masalah dan diragukan kemampuannya dalam menjawab tantangan zaman, terutama ketika berhadapan dengan arus moden.

Seiring berjalannya waktu desakan dan hantaman justru masuk dari sisi yang lain, yaitu globalisasi. Banyak fenomena yang membuat lingkungan sekitar sangat merinding, fakta menggambarkan bahwa sudah terjadi pemelesetan tunas bangsa dari beberapa aspek lini kehidupan. Banyak generasi yang bercokol tidak sebagai generasi yang subur. Pun demikian banyak sekali komunitas terpelajar yang berujar; bahwa keharuman negeri itu bisa dilihat bagaimana putra-putri bangsa ini.Pesantren Harus Akomodatif.

Ironis apabila perubahan zaman dinafikan, sebab perubahan itu justru akan menampilkan ciri kepribadian dan pencintraan pesantren itu dapat dipegang dengan kuat. Pesantren secara historis mampu menjadi benteng pertahanan, oleh KH. M. Sya'roni Ahmadi, beliau menjabarkan, bahwa urgensi pesantren sangat berperan aktif dalam kerangka memperjuangkan kemerdekaan sampai titik darah penghabisan. Kalau pesantren pada masa itu tidak memahami ahlussunnah wal jama'ah, tentu dapat kita gambarkan bagaimana agama yang akan dianut penduduk Indonesia secara mayoritas. Perlawanan ini tidaklah bermuara pada keterlibatan wawasan keagamaan saja, tetapi juga fisik dan mental untuk mengusir kaum penjajah yang selalu men-dzalimi bangsa Indonesia saat itu. 26

24. Hasbi Indra, Pendidikan Islam Melawan Globalisasi (Jakarta: Rida Mulia, 2005. Jakarta: PT Raja Grafindo Persada, 2012), 82-83.

25. Jalaluddin Rahmat, Islam Aktual Refleksi Sosial Seorang Cendikiawan Muslim, (Bandung: Mizan, 1996), 73.

26. Abdurrahman Wahid, Pesantren Masa Depan, ( Bandung: Pustaka Hidayah, 1999), 214. 
Bahkan sampai detik ini, pesantren tetap waspada dengan segala modernitas zaman, imperialisme budaya, deskontruksi moral, serta indikator lain yang begitu kuat merongrong dan mendesak budaya ketimuran secara hegemonik. Pesantren harus mampu menjadi muara peradilan agar tidak terseret kedalam arus itu, yang senantiasa menjebaknya dalam kehampaan spiritual.Secara kontinyu pesantren harus membuktikan kesuksesanya untuk menjawab tantangan zaman. Mengenai bagaimana masa depan pesantren selanjutnya, tentu ia harus mampu menjadi lembaga yang tanggap akan segala persoalan yang pluralistik tanpa menghilangkan jati dirinya. Masalah tersebut tampaknya harus diambil langkah kongkrit dengan sikapnya yang akomodatif. Artinya pesantren tidak hanya merem terhadap kemajuan dan perkembangan tekhnologi modern. Ia harus lebih intens dengan mengkaji agama sebagai rujukan.

\section{Problematika dan Tawaran Pengembangan Pesantren}

Realitas pendidikan Islam saat ini bisa dibilang stagnan tak ada perubahan yang cukup signifikan dari waktu ke waktu. Diantara indikasinya adalah, Pertama, minimnya upaya pembaharuan. Kedua, praktik pendidikan Islam sejauh ini masih memelihara warisan yang lama, dan tidak banyak melakukan pemikiran kreatif, inovatif, dan kritis terhadap isu-isu aktual. Ketiga, model pembelajaran pendidikan Islam terlalu menekankan pada pendekatan intelektualismeverbalistik dan menegasikan pentingnya interaksi edukatif dan komunikatif antara guru- murid. Keempat orientasi pendidikan Islam menitikberatkan pada pembentukan hamba Allah dan tidak seimbang dengan pencapaian karakter manusia muslim sebagai khalifah fi al-ardl.27 Hal inilah yang membuat mungkin masih banyak pesantren yang masih bertahan dengan sisi ketradisionalannya.

Ciri masyarakat masa depan itu antara lain pertama globalisasi. Kedua Perkembangan iptek yang makin cepat. Ketiga Arus komunokasi yang semakin padat dan cepat yang merubah masyarakat menjadi masyarakat informasi. Keempat Peningkatan layanan professional dalam berbagai segi kehidupan bangsa.

Dewasa ini masyarakat dilihat dari sudut teknologi dapat dibagi menjadi tiga kelompok yaitu: pertama, kelompok technological innovator, mencakup hanya 15 persen dari penduduk dunia, tetapi menguasai seluruh inovasi teknologi yang terdapat didunia ini. Kedua, kelompok technological adoptersmencakup dari setengah penduduk dunia, yaitu bangsa-bangsa yang mampu menguasai teknologi-teknologi baru hasil inovasi. Ketiga, kelompoktechnological exclude, mencakup kira-kira dari sepertiga penduduk dunia yang tidak mampu memperbaharui teknologi tradisional mereka dan tidak mampu pula menguasai inovasi-inovasi yang dihasilkan oleh masyarakat di luar wilayah kita.28

Kalau diperhatikan secara lebih mikro didunia pendidikan lebih terasa keterkucilan pesantren karena lokasi dan lingkungan yang umumnya terkucil

27. Abdurrahman Wahid, Pesantren Masa Depan, ( Bandung: Pustaka Hidayah, 1999), 157.

28. Mujamil Qomar, Pesantren dari Transformasi Metodologi Menuju Demokratisasi Intitusi,(Jakarta: Erlangga, 2008), 31-32. 
secara teknologis. Salah satu upaya untuk mengatasi tertinggalnya pesantren adalah memberikan mata pelajaran MIPA di pondok pesantren. Hal itu dibutuhkan sebagai dasar santri-santri yang ada dilingkungan pondok pesantren kedepannya bisa mengembangkan agama Islam dari berbagai bidang yang diminatinya, termasuk teknologi.

Tantangan atau problematika baru pesantren sebagai akibat dari arus globalisasi antara lain adalah :

a. Adanya penggunaaan sains dan teknologi dalam kehidupan masyarakat yang memengaruhi lahirnya pola komunikasi, interaksi, sistem pelayanan publik dan ain semacamnya.

b. Masuknya nilai-nilai budaya modern yang bercorak materialistik, hedonistik dan sekularistik yang menjadi penyebab dekadensi moral.

c. Interdependensi(kesaling-tergantungan) antara negara yang menyebabkan terjadinya dominasi dan hegemoni antara negara kuat atas negara yang lemah.

d. Meningkatnya tuntutan publik untuk mendapatkan perlakuan yang semakin adil, demokratis, egaliter, cepat dan tepat yang menyebabkan terjadinya fragmentasi politik.

e. Adanya kebijakan pasar bebas yang memasukkan pendidikan sebagai komoditas yang diperdagangkan.29

Persaingan dengan output dari pendidikan asing yang menjadi salah satu tantangan pesantren. Dalam dunia pendidikan Santoto $S$ hamijoyo, menawarkan lima strategi dasar dalam menghadapi problematika pendidikan di era globalisasi:

a. Pendidikan untuk pengembangan IPTEK terutama dalam bidang-bidang vital, seperti manufacturing dan pertanian.

b. Pendidikan untuk mengembangkan ketrampilan manajemen, termasuk bahasa asing sebagai instrument oprasional untuk berkiprah dalam globalisasi.

c. Pendidikan untuk pengelolaan kependudukan, lingkungan, keluarga berencana dan kesehatan sebagai penangkal penurunan kualitas hidup.

d. Pendidikan untuk pengembangan sistem nilai, termasuk filsafat, agama dan ideologi demi ketahanan sosial-budaya termasuk persatuan dan kesatuan bangsa.

e. Pendidikan untuk mempertinggi mutu tenaga kependidikan dan kepelatihan termasuk pengelola sistem pendidikan formal dan non formal, demi penggalakan peningkatan pemerataan mutu pendidikan. 30

Tantangan merupakan masalah yang harus dihadapi pesantren. Karena selama ini pesantren masih berorientasi dengan dunia dan hal-hal lama, padahal

29. Mujamil Qomar, Pesantren dari Transformasi Metodologi Menuju Demokratisasi Intitusi,(Jakarta: Erlangga, 2008), 77.

30. Mujamil Qomar, Pesantren dari Transformasi Metodologi Menuju Demokratisasi Intitusi,(Jakarta: Erlangga, 2008), 35-36 
dunia terus berjalan, banyak hal baru bermunculan dan pesantren lamban merespon hal-hal baru tersebut, sehingga ada anggapan bahwa pendidikan Islam lebih detail pesantren itu adalah lembaga kelas dua, lembaga pilihan terakhir.

\section{Manajemen Pesantren dalam Bingkai Globalisasi.}

Manajemen dalam kamus besar bahasa Indonesia memiliki arti proses pemakaian sumber daya secara efektif untuk mencapai sasaran yang telah ditentukan.31 James A.F Stoner mengemukakan bahwa manajemen adalah proses perencanaan pengorganisasian pengarahan dan pengawasan usaha-usaha para anggota organisasi dan penggunaan sumberdaya organisasi lainnya agar mencapai tujuan organisasi yang telah ditetapkan.32 Dari pengertian di atas dapat dimengerti manajemen dimulai dari sejak awal berdirinya sebuah lembaga.

Manajemen pendidikan adalah suatu sistem pengelolaan dan penataan sumber daya pendidikan, seperti tenaga kependidikan, peserta didik, masyarakat, kurikulum, dana keuangan, sarana dan prasarana pendidikan, tata laksana dan lingkungan pendidikan.33 Manajemen pendidikan Islam itu sendiri adalah suatu proses penataan atau pengelolaan lembaga pendidikan Islam yang melibatkan sumber daya manusia muslim dan menggerakkannya untuk mencapai tujuan pendidikan Islam secara efektif dan efisien sebagaimana dalam pengertian di atas. Pesantren merupakan bagian dari pendidikan Islam sehingga dapat ditarik kesimpulan bahwa manajemen pesantren sejalan dengan manajemen pendidikan Islam.

Globalisasi berasal dari kata the globe yang berarti bumi, dunia ini. Maka globalisasi secara sederhana dapat diartikan sebagai menjadikan semuanya satu bumi atau satu dunia. Jin Young Chung mendefinisikan globalisasi sebagai suatu proses terintegrasinya dunia melalui peningkatan arus capital, hasil-hasil produksi, jasa, ide dan manusia yang lintas batas negara. Globalisasi merupakan kelanjutan dari modernisasi, dan disisi lain globalisasi adalah proses pengintegrasian ekonomi nasional kepada sistem ekonomi dunia.34 Dalam merespon globalisasi dikalangan umat Islam ada tiga pandangan. Pertama, merespon dengan cara anti globalisasi. Kedua, sebagian yang lain terpengaruh oleh arus tersebut yang berakibat adanya pemisahan antara agama dan politik atau masalah-masalah keduniaan lainnya. Ketiga, sebagian bersikap kritis namun tidak secara otomatis anti barat. Kelompok ketiga ini bersahabat dan bekerja sama dengan barat, kelompok ini tidak terjangkit sekularisasi dan tetap sebagai pemeluk agama yang taat. Kelompok yang ketiga inilah yang sebaiknya diikuti oleh umat Islam, menyerap tetapi memiliki filter sehingga tidak kehilangan jati dirinya sebagai pribadi muslim.

31. Amin Haedari, Masa Depan Pesantren (Jakarta: IRD Press, 2004), 15.

32. DEPAG RI DIRJEN Kelembagaan Agama Islam, Pondok Pesantren dan Madrasah Diniyah Pertumbuhan dan Perkembangannya (Jakarta: DEPAG RI, 2003), 30.

33. Ridlwan Nasir, Mencari Tipologi Format Pendidikan Ideal (Yogyakarta: Pustaka Pelajar, 2005), 88.

34. Hasbi Indra, Pendidikan Islam Melawan Globalisasi (Jakarta: Rida Mulia, 2005. Jakarta: PT Raja Grafindo Persada, 2012), 65 
Globalisasi juga membawa keterbukaan informasi dalam Islam yang ditandai dengan makin mengecilnya sekat-sekat mazhab. Islam yang sekarang bukan lagi Islam yang sektarian. Kaum muslim tidak melihat mazhabnya. Mereka melihat dunia Islam yang tunggal Sehingga sudah tentu menuntut perkembangn model dakwah umat Islam, yang harus dilakukan oleh pesantren sebagai produsen ulama atau pendakwah.

Walaupun sekarang memasuki dunia global namun sudah menjadi common sense bahwa pesantren dekat dengan figur kyai. Masih banyak kyai yang anti dengan perubahan dunia global. Dalam manajemen pesantren Kyai adalah figure sentral, otoritatif, dan pusat seluruh kebijakan dan perubahan. Hal ini karena dua faktor utama yaitu: pertama,kepemimpinan yang tersentralisasi pada individu yang bersandar pada karisma serta hubungan yang bersifat patrenalistik. Kebanyakan pesantren menganut sistem serba mono: mono manajemen dan mono administrasi sehingga tidak ada delegasi kewenangan ke unit-unit kerja yang ada dalam organisasi. Kedua, kepemilikan pesantren yang bersifat individual(atau keluarga) bukan komunal. Implikasinya, gap quality (atau kesenjangan kualitas) antara seorang pemimpin dengan lainnya tidak bisa dihindarkan. Pola manajemen pendidikan dilakukan secara indental dan kurang memperhatikan tujuan-tujuannya yang telah disistemastisasikan secara hierarkis. Sistem pendidikan pesantren biasanya dilakukan secara alami dengan pola manajerial yang tetap sama dalam setiap tahunnya

Penyelenggaraan pondok pesantren dapat diungkap bahwa ada 3 faktor yang berperan yaitu : pertama, manajemen sebagai faktor upaya. Kedua, Organisasi sebagai faktor sarana. Dan ketiga, administrasi sebagai karsa. Dalam rangka menciptakan manajemen yang baik dalam menyelenggarakan pondok pesantren, maka fungsi-fungsi yang perlu diperhatikan dalam penyelenggaraan pesantren adalah perencanaan, penempatan, personil, financial (keuangan), supervise, dan evaluasi. Pesantren harus mewujudkan manajemen kurikulum, manajemen personalia, manajemen santri, manajemen keuangan, manajemen perpustakaan, manajemen informasi dan komunikasi, manajemen masyarakat atau lingkungan, manajemen struktur, manajemen teknik, manajemen bimbingan dan konseling, hingga manajemen konflik. Fungsi-fungsi manajemen dapat berjalan dengan normal. Muncullah perencanaan (planning) terhadap semua aspek baik kelembagaan, kurikulum, dan sebagaiya, pengorganisasian (organizing), penggerakkan (actuating), dan pengawasan (cotrolling). 35

Kiai menguasai dan mengendalikan seluruh sector kehidupan pesantren. Kedudukan kiai adalah kedudukan ganda: sebagai pengasuh sekaligus pemilik pesantren.kekuasaan mutlak itu pada gilirannya menyuburkan variasi pesantren, berbagai bentuk dan corak pesantren merupakan akibat dari kebijaksanaan kiai yang berbeda-beda dan tidak pernah diseragamkan. Ditambah pesantren terpolarisasikan ketika menghadapkan zaman, ada pesantren yang bersikap lunak dan ada yang keras. Ada pesantren yang terbuka, dan ada yang tertutup. 
Sehingga membuat pola manajemen pesantren kenyataan dilapangan juga bermacam-macam bentuknya.

\section{Manajemen Pesantren tradisional}

Dalam manajemen pesantren tradisional. Kiai menjadikan pesantren seolah-olah eksklusif, terasing dari kehidupan luar dan didukung kehidupannya yang unik. Umumnya beberapa pesantren tradisional berada di daerah peripheral yang jauh dari budaya urban. Dibeberapa pesantren kiai mengharamkan mata pelajaran umum, tidak ada yang berani menyangkal apalagi sampai menggoyahkan keputusan ini. Kondisi ini yang menyebabkan orang luar tidak boleh dan merasa tidak memiliki hak untuk mengajukan usulan-usulan kosntruktif-strategik dalam upaya pengembangan pesantren dimasa depan, pihak kiai sendiri tidak membuka ruang bagi pemikiran-pemikiran dari luar yang menyangkut penentan dari kebijakan pesantren. Pembelajaran ilmu-ilmu agama Islam dilakukan secara individu atau kelompok dengan konsentrasi pada kitabkitab klasik berbahasa Arab. Perjenjangan tidak didasarkan pada satuan waktu, tetapi berdasarkan tamatnya kitab yang dipelajari. Dengan selesainya satu kitab tertentu santri dapat naik jenjang dengan mempelajari kitab yang tingkat kesukarannya lebih tinggi. Alamsyah Ratu Prawiranegara juga mengemukakan beberapa pola umum yang khas yang terdapat dalam pendidikan Islam tradisional diantaranya sebagai berikut :pertama, Independen. Kedua, kepemimpinan tunggal. Ketiga, kebersamaan yang merefleksikan kerukunan. Keempat,Kegotong-royongan. Kelima, motivasi yang terarah dan pada umumnya mengarah pada peningkatan hidup beragama.

\section{Manajemen Pesantren Modern}

Pondok pesantren ini adalah pondok pesantren yang menyelenggarakan kegiatan pendidikan dengan pendekatan modern, melalui satuan pendidikan formal baik madrasah maupun sekolah. Pembelajaran pondok pesantren khalafiyah dilakukan secara berjenjang dan berkesinambungan dengan satuan program didasarkan pada satuan waktu, seperti semester, catur wulan. Dalam pondok pesantren modern kedudukan para kyai adalah sebagai koordinator pelaksana proses belajar-mengajar dan sebagai pengajar langsung dikelas.

\section{Manajemen Pesantren Komprehensif}

Pondok pesantren ini disebut komprehensif karena merupakan sistem pendidikan dan pengajaran gabungan antara tradisional dan yang modern. Pondok pesantren ini sebagaimana pondok pesantren modern, hanya saja lembaga pendidikannya lebih lengkap. Terutama dalam bidang ketrampilan dan benar-benar memperhatikan kualitasnya tetapi tidak menggeser cirri khusus kepesantrenannya yang masih relevan dengan kebutuhan masyarakat dan zaman.36 


\section{Penutup}

Pesantren sebagai lembaga pendidikan tertua yang masih bertahan hingga kini tentua saja harus sadar bahwa penggiatan diri yang hanya pada wilayah keagamaan tidak lagi memadai, maka dari itu pesantren harus proaktif dalam memberikan ruang bagi pembenahan dan pembaharuan sistem pendidikan pesantren dengan senantiasa harus selalu apresiatif sekaligus selektif dalam menyikapi dan merespon perkembangan dan pragmatisme budaya yang kian menggejala sehingga sangat diperlukan pembaharuan-pembaharuan yang harus dilakukan pesantren dalam menghadapi zaman modern.

Tantangan tunggal pesantren di masa modern adalah adanya gesekangesekan globalisasi atau bisa disebut dengan tantangan modernisasi yang bersifat kompleks. Dalam menghadapi tantangan zaman, pesantren juga harus senantiasa memegang prinsip-prinsip pembaharuan yaitu: memiliki kebijaksanaan menurut ajaran Islam,memiliki kebebasan yang terpimpin, berkemampuan mengatur diri sendiri,memiliki rasa kebersamaan yang tinggi, menghormati orang tua dan guru,cinta kepada ilmu, mandiri, kesederhanaan.

\section{DAFTAR PUSTAKA}

Amin Haedari, Masa Depan Pesantren (Jakarta: IRD Press, 2004)

Asegaf, Abdur Rahman, Pendidikan Islam di Indoonesia, ( Yogyakarta : Suka Press, 2007)

Asmani, Jamal Makmur, Manajemen Pengelolaan dan Kepemimpinan Pendidikan Profesional, (Yogyakarta: Diva Press, 2009)

DEPAG RI DIRJEN Kelembagaan Agama Islam, Pondok Pesantren dan Madrasah Diniyah Pertumbuhan dan Perkembangannya (Jakarta: DEPAG RI, 2003).

Indra, Hasbi, Pendidikan Islam Melawan Globalisasi (Jakarta: Rida Mulia, 2005. Jakarta: PT Raja Grafindo Persada, 2012)

Machali, Imam, Pendidikan Islam dan Tantangan Globalisasi, (Yogyakarta: Presma dan Ar-Ruzz Media, 2004)

Masyhud, Sulthon, Manajemen Pondok Pesantren (Jakarta: Diva Pustaka, 2005)

Nasir, Ridlwan, Mencari Tipologi Format Pendidikan Ideal (Yogyakarta: Pustaka Pelajar, 2005)

Nata, Abudin, Sejarah Sosial Intelektual Islam dan Institusi Pendidikannya..., 
Qomar, Mujamil, Pesantren dari Transformasi Metodologi Menuju Demokratisasi Intitusi,(Jakarta: Erlangga, 2008)

Rahardjo, Pergulatan Dunia Pesantren Dari Bawah (Jakarta: P3M, 1985)

Rahmat, Jalaluddin, Islam Aktual Refleksi Sosial Seorang Cendikiawan Muslim, (Bandung: Mizan, 1996)

Shulhan, Muwahid, Manajemen Pendidikan Islam, (Yogyakarta: Teras, 2013)

Shulhan, Muwahid, Manajemen Pendidikan Islam, (Yogyakarta: Teras, 2013)

Suismanto, Menelusuri Jejak Pesantren, (Yogyakarta: Alif press, 2004)

Tim Penyusun, Kamus Bahasa Indonesia, (Jakarta: Pusat Bahasa Departemen Pendidikan Nasional, 2008)

Tirtarahardja, Umar, Pengantar Pendidikan, (Jakarta: DIKTI DEPDIKBUD, 1994)

Wahid, Abdurrahman, Pesantren Masa Depan, ( Bandung: Pustaka Hidayah, 1999) 